(c) 2008 Plant Management Network.

Accepted for publication 8 August 2008. Published 15 October 2008.

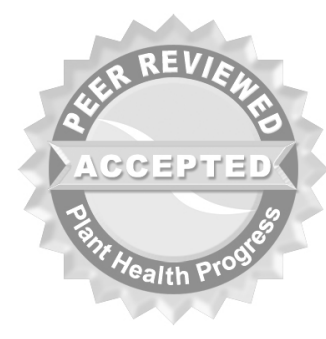

\title{
Efficacy of Pre-harvest Fungicide Applications and Cold Storage for Postharvest Control of Botrytis Fruit Rot (Gray Mold) on Red Raspberry
}

M. A. Ellis and L. V. Madden, Department of Plant Pathology, The Ohio State University-OARDC, 1680 Madison Avenue, Wooster, OH 44691; S. R. Wright, The Ohio State University, South Centers at Piketon, 1864 Skyville Road, Piketon, OH 45661; and L. L. Wilson, Department of Plant Pathology, The Ohio State University-OARDC, 1680 Madison Avenue, Wooster, OH 44691

Corresponding author: M. A. Ellis. ellis.7@osu.edu

Ellis, M. A., Madden, L. V., Wright, S. R., Madden, L. V., and Wilson, L. L. 2008. Efficacy of pre-harvest fungicide applications and cold storage for post-harvest control of botrytis fruit rot (gray mold) on red raspberry. Online. Plant Health Progress doi: 10.1094/PHP-20081015-01-RS.

\begin{abstract}
Applications of the fungicides Elevate 50WG and Switch 62.5WG to red raspberry prior to harvest were evaluated for post-harvest control of fruit rot, caused by Botrytis cinerea. Fungicides were applied three times during bloom only, three times pre-harvest (post-bloom) only, or six times full season (bloom through harvest), and symptomless fruit (at harvest) were incubated for 8 days in either cold storage $\left(4^{\circ} \mathrm{C}\right)$ or at room temperature $\left(23^{\circ} \mathrm{C}\right)$. Without fungicide, between 6 and $29 \%$ of the fruit had rot symptoms after 2 days of storage at room temperature over the 2 years of testing; after 8 days, 74 and $85 \%$ of the fruit had symptoms at room temperature. Zero and $12 \%$ of fruit had symptoms with 2 days of cold storage when plants were not treated with fungicide, and rot incidence increased to 9 and $60 \%$ at 8 days of cold storage over the 2 years. All fungicide treatments significantly reduced post-harvest fruit rot compared to the control (six water sprays). Applications of fungicide only at bloom generally had higher fruit rot incidence than found for the pre-harvest and full season fungicide programs. Results indicate that pre-harvest (post-bloom) fungicide sprays are beneficial for control of post-harvest Botrytis fruit rot, especially when coupled with cold-temperature storage.
\end{abstract}

\section{I ntroduction}

One of the major constraints to increased raspberry production and marketing worldwide is Botrytis fruit rot or gray mold, caused by the fungus Botrytis cinerea $(8,12)$. The raspberry is an aggregate fruit composed of about 100 drupelets. Its morphological characteristics contribute to its high susceptibility to fruit rots $(9,12)$. The lack of effective post-harvest control of gray mold is the most important single factor limiting the sale of fruits on distant markets (9). In Ohio, almost $100 \%$ of raspberry fruits are marketed as pick-your-own or direct retail in farm markets. Growers that market harvested berries often need to hold them in cold storage for at least 2 to 3 days for marketing purposes; however, many growers experience $100 \%$ loss of fruit in cold storage within 48 to $72 \mathrm{~h}$ due almost exclusively to rot caused by B. cinerea.

B. cinerea also causes gray mold of strawberry. Epidemiological studies have demonstrated that the majority of fruit infections on strawberry occur during bloom $(2,3,14)$. Studies on raspberry have had similar results $(4,6,18,19,20)$. Williamson et al. (20) reported that inoculation of flowers with dry conidia greatly reduced the shelf life of fruit after harvest. They also found that most fruits are symptomlessly infected via flower parts prior to harvest $(4,5,9,10)$. Jarvis (10) reported that mycelium infecting floral parts can invade the proximal end of both strawberry and raspberry receptacles. This mycelium generally remains quiescent (latent) until fruit begin to ripen, at which time the fungus becomes active and rots the fruit. Even under relatively dry environments, 
conidia can germinate in stigmatic fluid and symptomlessly colonize styles that remain attached to fruits at maturity $(4,8,12,20)$.

Due to the importance of flower infections, fungicide applications for gray mold control on strawberry and raspberry are currently targeted primarily during the bloom period $(2,3,4,8,11,17,20)$. On strawberry, bloom applications have been very effective for gray mold control in perennial production systems $(1,9,14,17)$. In perennial matted row strawberry production systems, there is a limited bloom period that makes it relatively efficient to protect the blooms with fungicides. Currently in Ohio, most strawberry growers apply fungicides for Botrytis fruit rot control during bloom, and discontinue spraying after bloom through harvest. This approach has provided excellent control on strawberry (17). On raspberry, bloom occurs over a much longer period of time and considerable bloom can be present during harvest. Many Ohio growers make applications to raspberry similar to those made on strawberry during the primary bloom period and generally stop sprays as harvest approaches.

Although this approach works very well on strawberry, our observations suggest that pre-harvest sprays on raspberries may be beneficial for post-harvest control of gray mold. Dashwood and Fox (4) suggested that multiple-spray programs on raspberry were essential to prevent both the early symptomless infection of fruit, as well as later surface contamination. The use of cold storage to aid in the reduction of post-harvest fruit rot is a clearly established and widely used cultural practice $(7,11,13)$. The objective of this study was to evaluate the effects of fungicide timing and cold storage on post-harvest fruit rot caused by $\mathrm{B}$. cinerea in raspberry.

\section{Fungicide Timing and Post-Harvest Storage Trials}

Fungicide evaluations were conducted in a 3-year-old commercial red raspberry planting at Moreland Fruit Farm, Moreland, OH, initially in 2003. Plants of the cultivar 'Nova' were grown in trellised rows on $3.6-\mathrm{m}$ (12- $\mathrm{ft}$ ) centers. Individual plots consisted of 4.6-m (15-ft) long sections of row. An untreated section of row was left between each treated section of row. Treatments were arranged in a completely randomized design with four replications per treatment. Fungicides were applied in 935 liters of water per ha (100 gal of water per acre) using a handgun at $1724 \mathrm{kPa}(250 \mathrm{psi}$ ) pressure. All treatments were applied to runoff. The fungicides Elevate (fenhexamid) and Switch (cyprodinil plus fludioxonil) were applied in a one or two-spray alternating program, with the first application for each timing period being Elevate and the last application being Switch. Switch has provided good control of post-harvest fruit rots on other crops (16); therefore, Switch was targeted for use in the last application before harvest.

Fungicide, rates and timing for each treatment in 2003 are provided in Table 1. Fruits were harvested from all treatments on three dates, 24 June, 29 June, and 4 July. At each harvest, 50 apparently healthy (symptomless) fruit (marketable fruit, red ripe) were hand harvested directly into 0.24-liter (2-pint) plastic clam shell containers. Fruits were picked carefully to avoid physical damage. Fruits were in contact with each other and all fruit could be observed without opening the container and moving the fruit. Two containers (each containing 50 fruit) were harvested from each replication, treatment, and harvest date. Containers were kept on ice in a cooler and within $1 \mathrm{~h}$ were immediately transported to the laboratory where one container per replication and treatment was placed on a laboratory bench at room temperature $\left(23^{\circ} \mathrm{C}\right)$ and the other container was placed in cold storage at $4^{\circ} \mathrm{C}$ and $95 \%$ relative humidity. On days $2,4,6$, and 8 of storage, the contents of each container were inspected for incidence of Botrytis fruit rot. Decayed fruit were left in the clamshell containers to replicate commercial conditions and also to prevent fruit damage and spread of inoculum that would accompany excessive handling (1). Disease incidence was recorded for each observation based on the presence of white mycelium, or presence of fungal sporulation. Visual diagnosis was confirmed by examination of sporulation with a hand lens or by plating out representative samples of aerial mycelium on acidified potato dextrose agar. 
Table 1. Percentage of raspberry fruits with Botrytis fruit rot (gray mold) symptoms after 8 days of post-harvest incubation at either room temperature $\left(23^{\circ} \mathrm{C}\right)$ or cold storage $\left(4^{\circ} \mathrm{C}\right)$ in 2003.

\begin{tabular}{|c|c|c|c|}
\hline \multirow[b]{2}{*}{ Treatment } & \multirow[b]{2}{*}{ Spray timing } & \multicolumn{2}{|c|}{$\begin{array}{l}\text { Fruit rot }(\%) \\
\text { at } 8 \text { days }\end{array}$} \\
\hline & & $\begin{array}{l}\text { Room } \\
\text { temp. }\end{array}$ & $\begin{array}{c}\text { Cold } \\
\text { storage }\end{array}$ \\
\hline $\begin{array}{l}\text { Application } \\
\text { only at } \\
\text { bloom }\end{array}$ & $\begin{array}{l}\text { Elevate } 50 \text { WG at } 1.68 \mathrm{~kg} \text { on } 22 \text { (early bloom) } \\
\text { and } 28 \text { May ( } 50 \% \text { bloom) ( } 2 \text { sprays); then } \\
\text { Switch } 62.5 \text { WG at } 980 \mathrm{~g} \text { on } 4 \text { June (late bloom) }\end{array}$ & $30.2 b^{z}$ & $0 \mathrm{~d}$ \\
\hline $\begin{array}{l}\text { Pre-harvest } \\
\text { applications } \\
\text { only }\end{array}$ & $\begin{array}{l}\text { Elevate } 50 \text { WG at } 1.68 \mathrm{~kg} \text { on } 14 \text { June (green } \\
\text { fruit present); then Switch } 62.5 \text { WG at } 980 \mathrm{~g} \text { on } \\
21 \text { (red fruit Present) and } 28 \text { June ( } 1 \text { day before } \\
\text { second harvest) }\end{array}$ & $9.7 \mathrm{c}$ & $0 \mathrm{~d}$ \\
\hline Full season & $\begin{array}{l}\text { All sprays in Bloom and Pre-harvest treatments } \\
\text { (above) }\end{array}$ & $9.5 \mathrm{c}$ & $0 \mathrm{~d}$ \\
\hline $\begin{array}{l}\text { Untreated } \\
\text { control y }\end{array}$ & - & $85.0 \mathrm{a}$ & $9.0 \mathrm{c}$ \\
\hline
\end{tabular}

z Means followed by the same letter within or across columns for incidence of fruit rot are not significantly different based on pair-wise comparison of leastsquares means using the least significant difference $(P=0.05)$. Analysis was based on the angular transformation of the proportion of visibly diseased fruit; mean transformed values were back-transformed to percentages for presentation purposes.

y Controls were sprayed with water only on all application dates (full season).

The entire experiment was repeated in 2004, with the same fungicide treatments and storage conditions. Fungicides, rates, and timing are presented in Table 2. Fruit were harvested from all treatments on 24 June, 29 June, and 4 July. Experimental procedures for harvesting, storage, and incubation of fruit were the same as described for 2003.

Table 2. Percentage of raspberry fruits with Botrytis fruit rot (gray mold) symptoms after 8 days of post-harvest incubation at either room temperature $\left(23^{\circ} \mathrm{C}\right)$ or cold storage $\left(4^{\circ} \mathrm{C}\right)$ in 2004.

\begin{tabular}{|c|c|c|c|}
\hline \multirow[b]{2}{*}{ Treatment } & \multirow[b]{2}{*}{ Spray timing } & \multicolumn{2}{|c|}{$\begin{array}{c}\text { Fruit rot }(\%) \\
\text { at } 8 \text { days }\end{array}$} \\
\hline & & $\begin{array}{l}\text { Room } \\
\text { temp. }\end{array}$ & $\begin{array}{l}\text { Cold } \\
\text { storage }\end{array}$ \\
\hline $\begin{array}{l}\text { Applications } \\
\text { only at } \\
\text { bloom }\end{array}$ & $\begin{array}{l}\text { Elevate } 50 \text { WG at1. } 68 \mathrm{~kg} \text { on } 15 \text { (early bloom) } \\
\text { and } 22 \text { May ( } 50 \% \text { bloom)( } 2 \text { sprays); then } \\
\text { Switch } 62.5 \text { WG at } 980 \mathrm{~g} \text { on } 28 \text { May (late bloom, } \\
\text { green fruit) }\end{array}$ & $18.3 c^{z}$ & $9.2 \mathrm{~cd}$ \\
\hline $\begin{array}{l}\text { Pre-harvest } \\
\text { applications }\end{array}$ & $\begin{array}{l}\text { Elevate } 50 \text { WG at } 1.68 \mathrm{~kg} \text { on } 4 \text { June (green } \\
\text { fruit); then Switch } 62.5 \mathrm{WG} \text { at } 980 \mathrm{~g} \text { on } 12 \text { (fruit } \\
\text { beginning to ripen) and } 19 \text { June ( } 1 \text { day before } \\
\text { first harvest) }\end{array}$ & $4.5 \mathrm{~cd}$ & $3.0 \mathrm{~d}$ \\
\hline Full season & $\begin{array}{l}\text { All sprays in Bloom and Pre-harvest treatments } \\
\text { (above) }\end{array}$ & $1.2 \mathrm{~d}$ & $1.2 \mathrm{~d}$ \\
\hline $\begin{array}{l}\text { Untreated } \\
\text { control y }\end{array}$ & - & $74.0 \mathrm{a}$ & $59.8 \mathrm{~b}$ \\
\hline
\end{tabular}

z Means followed by the same letter within or across columns for incidence of fruit rot are not significantly different based on pair-wise comparison of leastsquares means using the least significant difference $(P=0.05)$. Analysis was based on the angular transformation of the proportion of visibly diseased fruit; mean transformed values were back-transformed to percentages for presentation purposes.

y Controls were sprayed with water only on all application dates (full season). 
The experimental design in each year was a split plot with two repeated measures (15). The harvest time and the incubation time in storage (after harvest) were repeated measures. Treatment was the whole plot, and storage condition (room temperature or cold storage) was the sub-plot (storage conditions were randomized within each replication-treatment-harvest). Statistical analysis was conducted by fitting a linear mixed model to the data. Treatment, storage condition, and incubation time were considered as fixedeffect factors; replication (block), harvest time (within each replicationtreatment), and all interactions involving replication and harvest were considered random-effect factors (15). Analysis was based on the angular transformation of the percentage of fruit with rot symptoms $(\arcsin [\sqrt{ } \mathrm{x} / 100])$. When a factor effect or interaction was significant $(\mathrm{P} \leq \mathrm{0.05})$, then multiple comparisons of least squares means were conducted. Because there also was an interaction of season with one or more of the within-season factors, results are given separately for each year.

\section{Post-Harvest Fruit Rot 2003}

Fungicide treatment, storage condition, and incubation time all had highly significant $(\mathrm{P}<0.01)$ effects on the angular transformation of fruit rot symptoms. Moreover, there were significant interactions $(\mathrm{P}<0.01)$ of treatment and storage condition, and significant interactions $(\mathrm{P}<0.01)$ of incubation time with both treatment and storage condition. Therefore, the increase in fruit rot symptoms was different for two storage conditions and four treatments.

At 2 days after harvest at room temperature, $6 \%$ of the non-treated control fruit had gray mold symptoms (Fig. 1), even though all fruit were symptomless when harvested. At 4 days after harvest at room temperature, $27 \%$ of the control fruit had symptoms and/or signs of visible mycelia. By 8 days after harvest, $85 \%$ of the control fruit had gray mold. At 2 days after harvest at room temperature, none of the fruit from plots treated with fungicide showed any gray mold symptoms. By 8 days at room temperature, however, $30 \%$ of the fruit from the bloom-only treatment showed fruit rot symptoms. All fungicide treatments had significantly less Botrytis fruit rot than the untreated control at 8 days of roomtemperature storage (Table 1). Moreover, the pre-harvest only (application after bloom) and full-schedule treatments had significantly less Botrytis fruit rot than the bloom only treatment, and there were no significant differences in means between the pre-harvest and full-schedule treatments. Fungicide treatment after bloom (i.e., pre-harvest) or the full-season fungicide regime resulted in only about $10 \%$ fruit rot after 8 days of storage at room temperature. 


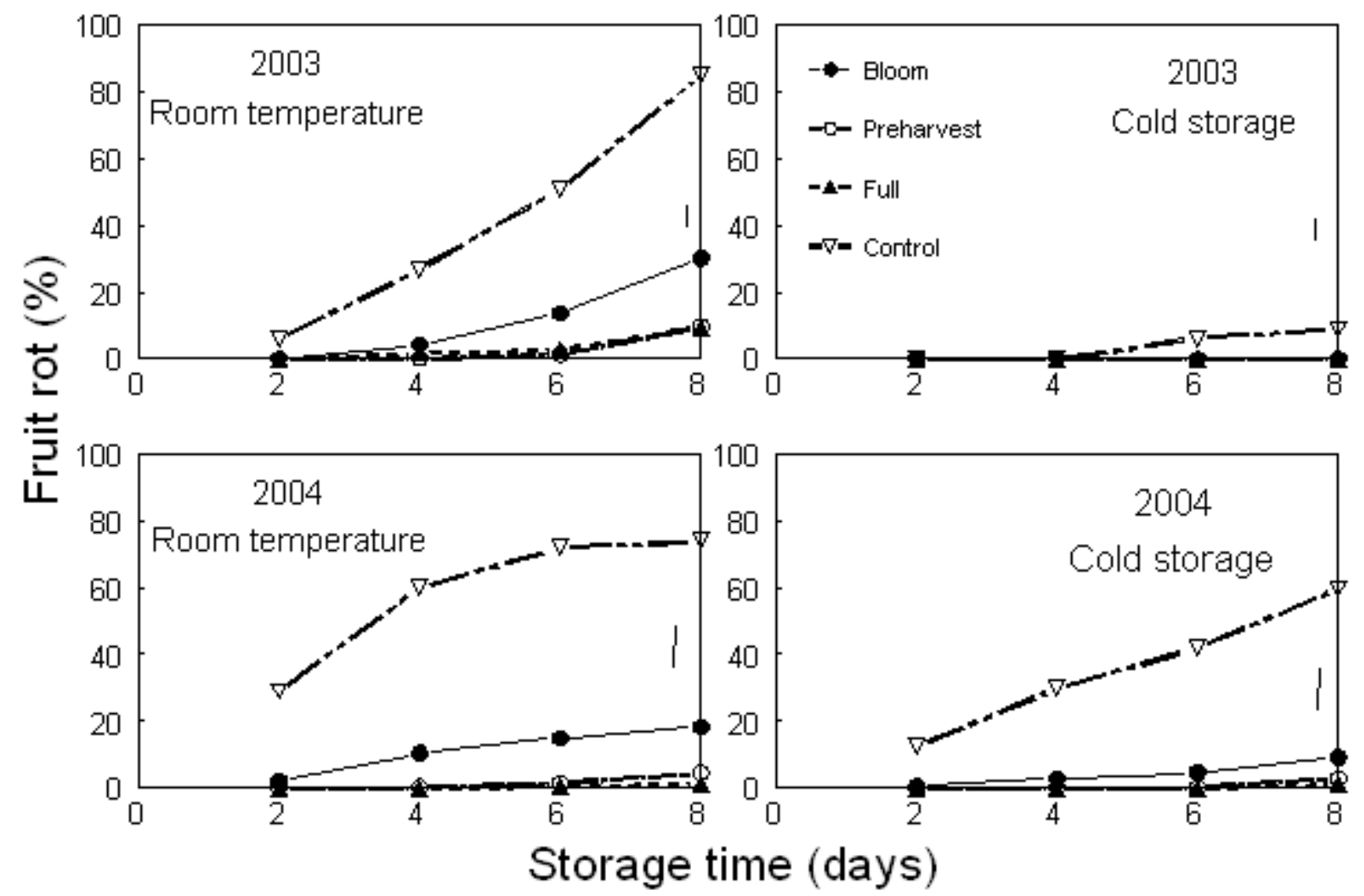

Fig. 1. Percentage of raspberry fruits with Botrytis fruit rot (gray mold) symptoms at 2 to 8 days of post-harvest incubation at either room temperature (left-hand graphs) $\left(23^{\circ} \mathrm{C}\right)$ or cold storage (right-hand graphs) $\left(4^{\circ} \mathrm{C}\right)$ in 2003 (upper graphs) and 2004 (lower graphs). Lines and symbols correspond to different treatments: fungicide sprays during bloom only, pre-harvest sprays (post-bloom), full schedule (combination of both bloom and pre-harvest sprays), and an unsprayed control. Labels in upper right graph correspond to all four graphs. Vertical bar is the least significant difference at $\mathrm{P}=0.05$, and is used to compare means across all treatments and times in a graph.

At 2 days of cold storage after harvest, there were no visible gray mold symptoms for any of the treatments, including the control (Fig. 1). Even after 8 days, fruit from the treatments receiving any fungicide (bloom, pre-harvest, or full season) showed no symptoms, and $9 \%$ of the fruit from the control treatment had gray mold symptoms (Table 1). At 8 days, the mean for the coldstorage control was significantly less then the mean for the room-temperature control, and also less than the mean for the room-temperature bloom-only fungicide treatment (Table 1).

Area under the disease progress curve (AUDPC) for fruit rot during days of storage was also analyzed (unpublished). Results were very similar to those obtained for incidence of fruit at 8 days of incubation (data not shown).

\section{Post-Harvest Fruit Rot 2004}

Fungicide treatment, storage condition, and incubation time all had highly significant $(\mathrm{P}<0.01)$ effects on fruit rot symptoms in 2004. There also was a highly significant $(\mathrm{P}<0.01)$ interaction of treatment and storage condition, and significant interactions $(\mathrm{P}<0.01)$ of incubation time with both treatment and storage condition.

Post-harvest fruit rot incidence was initially higher in 2004 than in 2003, especially for the untreated fruit (Fig. 1). Variability was also higher than in 2003. At 2 days after harvest at room temperature, $29 \%$ of the non-treated control fruit had gray mold symptoms. With 8 days of storage, $74 \%$ of the control fruit had gray mold symptoms. At 2 days, none of the fruit from the preharvest (post-bloom) or full-season fungicide treatments showed symptoms; however, $2 \%$ of the fruit from the bloom-only treatment had fruit rot symptoms. By 8 days of storage at room temperature, $18 \%$ of the fruit from the bloom-only treatment, but only $4.5 \%$ of the fruit from the pre-harvest treatment and $1.2 \%$ of the fruit from the full-season treatment showed symptoms (Fig. 1). With 8 days of storage, fruit rot incidence was significantly greater for the control than for 
the other treatments (Table 2). Moreover, rot incidence for the full season treatment was less than for the bloom-only treatment.

At 2 days of cold storage, $12 \%$ of the fruit from the non-treated control treatment had Botrytis fruit rot symptoms (Fig. 1); this is in contrast to $0 \%$ in 2003 for the same conditions. Incidence increased to $60 \%$ by day 8 for the coldstorage control. There were no fruit with gray mold at 2 days of cold storage for the three fungicide treatments. At 8 days of cold storage, fruit rot incidence for the fungicide treatments ranged from 1.2\% (full-season) to $9 \%$ (bloom). Means for the fungicide treatments were all significantly $(\mathrm{P}=0.05)$ less than for the control with cold storage (Table 2). Moreover, with the controls, the mean for cold storage was significantly less than the mean for room temperature at 8 days of incubation.

Analysis of AUDPC gave the same general results as found for fruit disease incidence at 8 days of storage, and results are not shown.

\section{I mplications for Control of Post-Harvest Fruit Rot on Raspberry}

Results for the control of post-harvest Botrytis fruit rot of red raspberry were similar in 2003 and 2004. Without fungicide treatment before harvest, unacceptable levels of fruit rot were found after only 2 days of storage at room temperature, even though all fruit were symptomless at time of harvest. At room temperature, all fungicide treatments resulted in significantly less post-harvest fruit rot than the untreated control. There also was a tendency for fruit rot incidence to be lower when fungicides were applied during pre-harvest (after bloom), or during bloom and pre-harvest (full season), compared to when fungicide was applied only during bloom. Even under the very extreme situation of 8 days of fruit storage at room temperature, less than $10 \%$ of the raspberry fruit showed symptoms of gray mold when fungicides were applied pre-harvest or for the full season.

Cold storage clearly reduced the incidence of fruit rot symptoms when plants were not treated with fungicides in the field. Cold-storage alone would not be adequate for controlling the disease post-harvest, since in 2004 about $12 \%$ of the fruit showed gray mold symptoms after only 2 days of storage when plants were not treated with fungicide in the field. All fungicide treatments resulted in excellent control of post-harvest Botrytis fruit in cold storage. At 2 days of cold storage, $\mathrm{o}$ or close to $\mathrm{o} \%$ fruit rot was found; after 4 days of cold storage, no fruit with disease symptoms were found for the pre-harvest or full-season fungicide treatments during both years. After 8 days of cold storage, the highest fruit rot incidence for the treatments receiving fungicide over the 2 years was $9 \%$ (bloom only), and most treatments had incidence of $1 \%$ or less.

In summary, Elevate and Switch provided excellent post-harvest control of Botrytis fruit rot in red raspberry in 2 years of studies. When fungicide treatments were combined with cold storage, disease control was enhanced. If growers intend to hold raspberries for as little as 2 days after harvest, the importance of maintaining good cold storage facilities cannot be over emphasized. However, even with good cold storage, fungicide use (especially during pre-harvest and possibly for the full season) appears to be beneficial for control of post-harvest fruit rot. We need to emphasize that the results of our studies apply only to control of post-harvest fruit rot by B. cinerea. In both years of testing very little fruit rot was observed in the controls at harvest in the field and only healthy (marketable) fruits were selected for use in storage studies. We do not intend to suggest that applications of fungicide during bloom are not important for control of Botrytis fruit rot, especially at harvest. Our data does suggest that pre-harvest applications of effective fungicides are beneficial for controlling post-harvest fruit rot. 


\section{Literature Cited}

1. Blacharski, R. W., Barty, J. A., Xizo, C. L., and Legard, D. E. 2001. Control of postharvest Botrytis fruit rot with pre-harvest fungicide applications in annual strawberry. Plant Dis. 85:597-602.

2. Braun, P. G., and Sutton, J. C. 1987. Inoculum sources of Botrytis cinerea in fruit rot of strawberries in Ontario. Can. J. Plant Pathol. 9:1-5.

3. Bristow, P. R., McNicol, R. J., and Williamson, B. 1986. Infection of strawberry flowers by Botrytis cinerea and its relevance to gray mold development. Ann. Appl. Biol. 109:545-554.

4. Dashwood, E. P., and Fox, R. A. 1988. Infection of flowers and fruits of red raspberry by Botrytis cinerea. Plant Pathol. 37:423-430.

5. Ellis, M. A., Converse, R. H., Williams, R. N., and Williamson, B., eds. 1991. Compendium of Raspberry and Blackberry Diseases and Insects. American Phytopathological Society, St. Paul, MN.

6. Freeman, J. A., and Pepin, H. S. 1976. Control of pre- and post-harvest fruit rot of raspberries by field sprays. Acta Hort. 60:73-80.

7. Galletta, G. J., and Himelrick, D. G. 1990. Small Fruit Crop Management. PrenticeHall Inc. Englewood Cliffs, NJ.

8. Jarvis, W. R. 1962. The infection of strawberry and raspberry fruits by Botrytis cinerea. Fr. Ann. Appl. Biol. 50:569-575.

9. Mason, D. T., and Dennis, C. 1978. Post-harvest spoilage of Scottish raspberries in relation to pre-harvest fungicide sprays. Hort. Res. 18:41-53.

10. Mass, J. L. 1980. Postharvest diseases of strawberry. Pages 329-353 in: The Strawberry. N. F. Childers, ed. Horticultural Publ., Gainsville, FL.

11. Mass, J. L., ed. 1998. Compendium of Strawberry Diseases, 2nd Edn. American Phytopathological Society, St. Paul, MN.

12. McNicol, R. J., Williamson, B., and Dolan, A. 1985. Infections of red raspberry styles and carpels by Botrytis cinerea and its possible role in post-harvest gray mold. Ann. Appl. Biol. 106:49-53.

13. McNicol, R. J., Williamson, B., and Dolan, A. 1990. Effects of inoculation, wounding and temperature on post-harvest gray mold (Botrytis cinerea) of red raspberry. J. Hort. Sci. 65:157-165.

14. Powelson, R. L. 1960. Initiation of strawberry fruit rot caused by Botrytis cinerea. Phytopathology 50:491-494.

15. Schabenberger, O., and Pierce, F. J. 2002. Contemporary Statistical Models for the Plant and Soil Sciences. CRC Press, Boca Raton, FL.

16. Sholberg, P. L., Bedford, K. E., and Stokes, S. 2003. Effect of pre-harvest applications of cyprodinil on post-harvest decay of apples caused by Botrytis cinerea. Plant Dis. 87:1067-1071.

17. Wilcox, W. F., and Seem, R. C. 1994. Relationship between strawberry gray mold incidence, environmental variables, and fungicide applications during different periods of the fruiting season. Phytopathology 84:264-270.

18. Williamson, B., and Duncan, G. H. 1989. Use of cryo-techniques with scanning electron microscopy to study infection of mature red raspberry fruits by Botrytis cinerea. New Phytolog. 111:81-88.

19. Williamson, B., and McNicol, R. J. 1986. Pathways of infection of flowers and fruits of $m$ red raspberry by Botrytis cinerea. Acta Hort. 183:137-141.

20. Williamson, B., McNicol, R. J., and Dolan, A. 1987. The effect of inoculating flowers and developing fruits with Botrytis cinerea on post-harvest gray mold on red raspberry. Ann. Appl. Biol. 111:285-294. 